\title{
Program „Teatr, Mama, Tata i Ja” w kontekście założeń koncepcii Twórczej Resocjalizacii
}

\author{
The "Theatre, Mum, Dad and Me" Program in the \\ Context of the Concept of Creative Rehabilitation
}

\begin{abstract}
ABSTRAKT
Przedstawiony w artykule problem odnosi się do procesu resocjalizacji osób pozbawionych wolności. Jego głównym celem jest przyirzenie się alternatywnemu do tradycyjnego sposobowi pracy ze skazanymi, tzw. resocjalizacji twórczej, oraz dostarczenie szerszej wiedzy na temat jej zastosowania w polskim więziennictwie. Główne założenia metodyczne tego sposobu resocjalizacji zostały przedstawione z wykorzystaniem współcześnie dostępnego i realizowanego przez Areszt Śledczy w Kielcach programu stosowanego wobec osób pozbawionych wolności - „Teatr, Mama, Tata i Ja”. Rozważania dotyczqce tego programu resocjalizacyjnego zostały dopełnione osobistym doświadczeniem byłego skazanego, przekazanym w toku przeprowadzonego wywiadu narracyjnego. Ukazana w artykule problematyka może się stać zachętą do większego zaangażowania kadry specjalistycznej w projektowanie, a także realizację programów z zakresu resocjalizacji twórczej w środowisku penitencjarnym oraz do korzystania z szerokiego wachlarza oferowanych przez niq metod. Jak ukazuja wyniki przeprowadzonych badań, resocjalizacja
\end{abstract}

SLOWA KLUCZOWE twórcza resocjalizacja, skazany, rozwój potencjałów, wartości, osobowość, programy penitencjarne

\section{KEYWORDS}

creative rehabilitation, convict, development of potentials, values, personality, penitentiary programs

SPI Vol. 24, 2021/5

ISSN 2450-5358 e-ISSN 2450-5366 DOI: 10.12775/SPI.2021.5.006 Nadesłano: 14.12.2021 Zaakceptowano: 22.12.2021 Raporty z badań 
w tym wydaniu posiada ogromny wpływ na rozwój potencjałów i przeobrażanie świata wartości jednostek. Pozwala kształtować własny światopoglad, odnawiać kontakty z bliskimi oraz prawidłowo adaptować się do wymogów i warunków życia.

\section{ABSTRACT}

The problem presented in the article refers to the process of rehabilitation of the incarcerated persons. Its main goal is to look at an alternative to the traditional way of working with prisoners, the so-called creative rehabilitation, and to provide more extensive knowledge on its application in the Polish penitentiary system. The main methodological assumptions of the method of social rehabilitation were presented using the program currently implemented by the Detention Ward in Kielce and applied to the incarcerated persons - "Theater, Mom, Dad and Me". Reflections regarding this rehabilitation program were complemented by the personal experience of the former prisoner, provided in the course of the narrative interview. The issues presented in the article may become an incentive for greater involvement of specialist staff in the designing and implementation of programs in the field of creative rehabilitation in the penitentiary system and to use a wide range of methods offered by them. As the results of the research show, social rehabilitation in this version has a huge impact on the development of potentials and the transformation of the values of individuals. It allows to shape one's own worldview, to renew contacts with loved ones and properly adapt to the requirements and conditions of life.

\section{Wprowadzenie}

Powszechna dostępność badań naukowych, a także szerokie pola ich zainteresowań w znaczny sposób zwiększyły zakres resocjalizacji. Ponadto mnogość działań i zachowań o charakterze dewiacyjnym, a wręcz patologicznym, zmusza praktykę penitencjarną do poszukiwania coraz to nowszych form, metod i środków oddziaływań na skazanego. Jedną z takich metod jest tzw. „twórcza resocjalizacja”.

Według Marka Konopczyńskiego twórcza resocjalizacja „przyjmuje nieco inną perspektywę. Przez swoje metody chce odnaleźć, rozwinąć i społecznie zaadaptować ludzkie potencjały. Jej podstawowym założeniem jest stymulowanie i rozwijanie strukturalnych 
czynników i mechanizmów procesów twórczych osób nieprzystosowanych społecznie. Rozwinięte i urealnione czynniki strukturalne mają pomóc w konstruowaniu nowych sposobów rozwiązywania sytuacji problemowych przez osoby nieprzystosowane społecznie" (Konopczyński 2007: 285).

Resocjalizacja twórcza poprzez swoje oddziaływania stara się wywierać stymulujący wpływ zarówno na sferę indywidualną jednostki, jak i na wymiar życia społecznego człowieka oraz jego kontakty interpersonalne. Efekty takich działań resocjalizacyjnych osiągają często zamierzony cel główny, ale także przynoszą realizację celów ubocznych. Po pierwsze, umożliwiają zainteresowanemu twórcze działanie, a także rozwój własnej tożsamości. Po drugie, kształtują szereg umiejętności, które posiadają pozytywne znaczenie w kontaktach międzyludzkich i życiu poza placówką zamkniętą. Do skutków ubocznych możemy zaś zaliczyć wytwory materialne, które powstają w procesie resocjalizacji, sprawiające, że dana jednostka może być uznana za artystę w konkretnej dziedzinie. „Mówiąc innym językiem, człowiek zajmujący się teatrem, sportem, plastyką czy muzyką i odnoszący w tym względzie jakieś sukcesy (poprzez granie roli w teatrze, namalowanie obrazu czy dobre występy sportowe) jest łatwiejszy do zaakceptowania przez innych ludzi niewykazujących zaburzeń patologicznych" (Konopczyński 2008: 71).

Marek Konopczyński, który od lat rozwija koncepcję twórczej resocjalizacji, ukazuje dobroczynny wpływ tego rodzaju działań resocjalizacyjnych na procesy myślowe i emocjonalne, które dokonują się poprzez rozwój twórczy: „Człowiek, który się rozwija przez obcowanie z nowymi dla niego elementami kultury i sztuki, poszerza i pogłębia swoje emocje, percepcję, myślenie i wyobraźnię. Jeśli przyjmiemy założenie, że twórcze rozwiązywanie sytuacji problemowych oraz nabyte dzięki temu nowe cechy tożsamościowe zaspokajają potrzeby człowieka w sposób akceptowany społecznie, to w dużym stopniu minimalizujemy niebezpieczeństwo kontynuacji jego patologicznych zachowań, redukując lub przynajmniej minimalizując wszelkie negatywne dla tożsamości młodego człowieka skutki wadliwych procesów socjalizacyjnych” (Konopczyński 2007: 268).

Resocjalizacja twórcza przyjmuje zatem inną perspektywę metodyki pracy niż pedagogika resocjalizacyjna. Można by rzecz, że stara się dopełnić swoimi treściami jej luki w teorii i praktyce, a także 
założenia badaczy i praktyków podejmujących trud pracy z osobami niedostosowanymi społecznie. „Twórcza Resocjalizacja sięga do dorobku nauk zajmujących się procesami twórczymi człowieka i czyni z nich bazę umożliwiającą uzyskiwanie zakładanych efektów" (Konopczyński 2012: 36).

Tak rozumiana resocjalizacja zakłada charakterystyczny dla siebie cel główny: „generalnym celem twórczej resocjalizacji, sięgającej do dorobku teoretycznego i metodologicznego koncepcji interakcyjnych oraz koncepcji kognitywnych, jest doprowadzenie do zaistnienia i pomyślnego zakończenia dwóch procesów. Pierwszy z nich polega na wzbudzaniu rozwoju strukturalnych czynników procesów twórczych i poznawczych jednostek nieprzystosowanych społecznie, drugi zaś na zmianie ich zewnętrznego wizerunku społecznego" (Konopczyński 2018: 67).

W tym miejscu należy zwrócić uwagę na zagadnienie tożsamości osobowej, które jest charakterystyczne dla nauk socjologicznych, filozoficznych oraz pedagogicznych. Wiąże się ona z wykształceniem światopoglądu, stylu życia oraz norm etycznych i wartości jednostki. Nie sposób więc nie odnieść się do zagadnienia „nowych tożsamości”, które stanowi podwaliny koncepcji doboru metod oddziaływania. Według Konopczyńskiego „pojęcie «nowych tożsamości» jest pojęciem kluczowym w omawianej koncepcji. Tak rozumiana twórcza resocjalizacja jest nauką o potencjalności osób nieprzystosowanych społecznie. Oznacza to, że jej metody mają za zadanie poszukiwać i rozwijać zarówno potencjały tkwiące w tych osobach, jak i stwarzać perspektywy wykreowania nowej tożsamości indywidualnej i społecznej osób nieprzystosowanych. Takie ujęcie problemu nie przeciwstawia koncepcji twórczej resocjalizacji koncepcjom tradycyjnym" (Konopczyński 2014: 20).

Predyspozycje z zakresu twórczości zyskały w ostatnich latach na sile, równocześnie stając się konieczne w realizacji celów stawianych $\mathrm{w}$ procesie wychowania, a także resocjalizacji osób pozbawionych wolności. Pomagają one w utrzymaniu równowagi emocjonalnej oraz rozwijaniu zasobów, które jednostka posiada i dzięki resocjalizacji twórczej może rozwijać. Należy się więc zgodzić z Ewą Wysocką i Barbarą Ostafińską-Molik, że „twórczość jako szczególny rodzaj aktywności, w największym stopniu wyzwalający potencjały jednostki, służy bezpośrednio rozwojowi jej osobowości, a także wewnętrznej 
przemianie stanowiącej w swej istocie cel resocjalizacji, co dokonuje się przez angażowanie własnych zdolności, które w aktywności twórczej się ujawniają"(Wysocka, Ostafińska-Molik 2019: 150).

\section{Metodologia badań - analiza badań pilotażowych}

Potrzeba przeprowadzenia badań pedagogicznych wyrasta z problemu, który ściśle nawiązuje do potrzeb społecznych. W związku z tym możemy założyć, że jego rozwiązanie w mniejszym lub większym stopniu przyczyni się do ulepszenia pracy zarówno z młodszymi, jak i starszymi zainteresowanymi, np. dziećmi czy dojrzałymi dorosłymi.

Niestety nie wszystkie badania przynoszą zamierzone rezultaty i nierzadko prowadzą do formułowania nieefektywnych rozwiązań. W takim przypadku cenna zdaje się być u badacza świadomość swoich niepowodzeń oraz chęć do usprawnienia własnej pracy. „Pomimo nie zawsze uwieńczonych spodziewanymi wynikami badań pedagogicznych, warto i trzeba podejmować je również w tym celu, by rzeczywiście mogły one służyć praktyce pedagogicznej. Podejmowane jedynie np. dla osobistej satysfakcji, w tym także zaspokojenia własnej ciekawości, nie służyłyby swemu przeznaczeniu, jakie wynika choćby z charakteru pedagogiki jako nauki praktycznej, a nie tylko teoretycznej” (Eobocki 2010: 16).

Ważne jest, aby badania z zakresu pedagogiki nie były tylko sposobem na zapełnienie pewnych luk w teorii i praktyce, natomiast by przyczyniały się do jej naukowego rozwoju, a także doskonalenia pracy w przestrzeni wychowawczej. W tym miejscu należy podkreślić również wagę znajomości podejmowanego problemu, umiejętność krytycznego myślenia, jak i korzystania z wyników uprzednio przeprowadzonych badań o pokrewnej tematyce.

W odniesieniu do praktyki penitencjarnej i procesu resocjalizacji należy zwrócić szczególną uwagę na poszukiwania zależności i rozwiązań, które mogą usprawnić działania względem skazanych oraz które będą doprowadzały grupy badaczy do ciekawych wniosków. Poprzez to jesteśmy w stanie wywierać wpływ na efektywność i sens samego procesu resocjalizacji, który niejednokrotnie poddawany był krytyce. Piszą o tym między innymi Wiesław Ambrozik w swojej 
publikacji Pedagogika resocjalizacyjna (2016) czy Henryk Machel w książce Sens ibezsens resocjalizacji penitencjarnej- casus polski (2006).

Przesłanki, wedle których badacz podąża, są nieoderwalnie związane z określeniem przedmiotu badań. Jest to kluczowy element tworzenia problematyki, na której mają zostać oparte rozważania. Należy pamiętać, że przedmiot badań jest mocno zakorzeniony w obranym temacie pracy. Pozwala nam na udzielenie odpowiedzi na pytanie co badano?

Przedmiotem referowanych w artykule badań pilotażowych był obraz resocjalizacji twórczej w perspektywie analizowanych wytworów oraz opinii respondenta pozyskanej w toku przeprowadzonego wywiadu narracyjnego.

Każde działanie badawcze jest podejmowane $\mathrm{z}$ zamiarem uzyskania pewnych efektów. Postawienie celów badawczych jest jednym $z$ podstawowych elementów w projektowaniu oraz późniejszym przeprowadzaniu badań naukowych. Za cel działań badawczych $\mathrm{w}$ danym przypadku przyjmuje się uzyskanie wiedzy na temat zastosowania resocjalizacji twórczej we współczesnej penitencjarystyce. Ponadto badania koncentrują się na zobrazowaniu związku między programem stosowanym wobec osób pozbawionych wolności, opartym na założeniach resocjalizacji twórczej, a potencjalną zmianą osobowości u skazanych.

Badania wpisują się w strategię i koncepcję badań jakościowych, gdyż wykorzystane zostały mechanizmy analizy literatury, tj. artykułów naukowych oraz nagrań audiowizualnych, a także narracyjny wywiad biograficzny $\mathrm{z}$ byłym skazanym, przeprowadzony z wykorzystaniem serii pytań wewnętrznych oraz zewnętrznych. W związku z ograniczoną dostępnością do oryginalnych dokumentów wykorzystane zostały materiały już opracowane, tj. artykuł Anny Dąbrowskiej, Justyny Kusztal i Małgorzaty Turczyk Wsparcie procesu readaptacji spotecznej skazanych na przyktadzie programu „Teatr, Mama, Tata i Ja” (2019).

Badanym respondentem był 48-letni mieszkaniec podkieleckiej miejscowości, obecnie przykładny mąż i ojciec. Wybór danej osoby miał charakter celowy. W związku z ówczesnym destrukcyjnym sposobem życia, a także faktem transformacji tożsamości respondenta dokonanej na skutek uczestnictwa $\mathrm{w}$ programie penitencjarnym z zakresu resocjalizacji twórczej, zdaje się być on idealnym przykładem na ukazanie związku między zmianą postaw i schematów 
poznawczych a czynnym uczestnictwem w zajęciach rozwijających skazanych pod kątem twórczości.

\section{Resocjalizacja twórcza na przykładzie programu „Teatr, Mama, Tata i Ja" oraz doświadczenia jednego z uczestników projektu}

\section{Charakterystyka programu}

Program „Teatr, Mama, Tata i Ja” jest projektem z zakresu wsparcia readaptacji i powrotu do społeczeństwa skazanych odbywających kary pozbawienia wolności. Jego pierwsza edycja miała miejsce w 2015 roku. Kolejne, coroczne edycje realizowane są przez Areszt Śledczy w Kielcach przy współpracy z miejscowym Teatrem Lalki i Aktora „Kubuś”. Wsparcie finansowe zapewniają również liczne organizacje pozarząadowe, rządowe, a także podmioty gospodarcze i wspierające rodzinę. W 2016 roku program został objęty patronatem honorowym byłego prezydenta miasta Kielce - Wojciecha Lubawskiego.

Program koncentruje się na odbudowywaniu więzi społecznych wychowanków. Należy zaznaczyć, że sam pobyt w placówce zamkniętej w dużej mierze ogranicza możliwość bliskości, rozmowy i funkcjonowania w wartościowej grupie. Elementem kluczowym zdaje się być możliwość utrzymywania kontaktu z rodziną, a przede wszystkim z dziećmi skazanych.

Program zapewnia pełną anonimowość. Powstaje wiele wystaw ze zdjęciami obrazującymi pracę podczas warsztatów, natomiast zostaje zachowana ochrona danych osobowych i wizerunku zarówno skazanych rodziców, jak i ich pociech.

\section{Cele programu}

Konstruując programy stosowane wobec osób pozbawionych wolności, należy jasno i precyzyjnie określić cele programu, tak aby oczywiste stały się efekty, które personel chciałby osiągnąć poprzez oddziaływanie na wychowanków.

Program „Teatr, Mama, Tata i Ja” jest „innowacyjnym przedsięwzięciem, które bazuje na nowatorskich działaniach edukacyjno-animacyjnych, stymulujących kreatywność i aktywizujących 
twórczo grupę osób pozostających poza obiegiem życia społecznego i kulturalnego. Zaplanowane zadania przyczyniają się pośrednio do osiągnięcia kilku celów” (Dąbrowska, Kusztal, Turczyk 2019: 350).

Pierwszy z celów, które zakłada niniejszy program, odnosi się do wzmacniania więzi rodzinnych skazanych. Ponadto program ma w założeniu przygotować wychowanka do poprawnego funkcjonowania w środowisku otwartym, dlatego też angażuje go do samodzielnych czynności bez asysty chociażby strażnika poza aresztem.

Kolejny cel ukierunkowany jest na pobudzenie w skazanych poczucia sprawstwa i samodzielności oraz samostanowienia. Dzieje się to między innymi w wyniku współpracy w ramach projektu z kadrą i animatorami. Uczestnik uczy się odpowiedzialności, a także odczuwa chęć uczestnictwa w wydarzeniach kulturowych.

Trzeci cel zakłada, że poprzez aktywny udział w warsztatach skazani, a także bliskie im osoby, będą wzmacniać poczucie własnej wartości oraz rozwijać swoje zainteresowania i talenty.

Realizacja celów programu przynosi pozytywne skutki nie tylko w odniesieniu do samych osadzonych, ale również jest pomocna kadrze więziennej i animatorom prowadzącym zajęcia. Tutaj celem staje się wzrost kompetencji i umiejętności wdrażania nowych, atrakcyjnych dla skazanych programów terapeutycznych.

\section{Podejmowane działania}

Aktywność w ramach jednej edycji programu ma charakter całoroczny i obejmuje cykl dziewięciu czterogodzinnych spotkań poza murami placówki przeprowadzanych jeden raz w miesiącu na terenie Teatru „Kubuś” w Kielcach. Pierwsze spotkanie, organizacyjne, polega na zapoznaniu się ze specyfiką funkcjonowania teatru, wspólnym uczestnictwie w spektaklu oraz zwiedzaniu pomieszczeń należących do teatru. „Klimat miejsca, w którym realizowany jest projekt, przyjazne relacje z organizatorami przedsięwzięcia oraz obecność osób bliskich skazanym stanowią elementy służące budowaniu lub umacnianiu więzi, sprzyjają procesowi przekształcania się ról odgrywanych w społeczeństwie, wpływają na zmianę samooceny, a w konsekwencji stanowią początek działań o charakterze przystosowania się do warunków wolnościowych”(Dąbrowska, Kusztal, Turczyk 2019:351). 
Również kolejne spotkania odbywają się w atmosferze szacunku i zrozumienia. Warsztaty oparte na metodach i technikach pracy wykorzystywanych $\mathrm{w}$ teatrze pozwalają na uzewnętrznienie potencjałów i zaangażowania w widowisko skazanych. Umożliwiają odbudowywanie pozytywnych relacji z otaczającymi ich ludźmi i światem. Co ważne, projekt cieszy się dużym zainteresowaniem wśród skazanych matek i ojców. Świadczy o tym wypowiedź jednej ze skazanych: „Bardzo liczę na to, że się dostanę do drugiej edycji projektu. To mi daje nadzieję i z uśmiechem na twarzy odliczam dni do następnego roku. Ten program znaczy dla mnie bardzo wiele. Zacieśnił moje więzi z synem, z mamą. Pozostały piękne wspomnienia, zdjęcia, przeżycia, do których ciągle wracam. Ten program bardzo wspomaga rodziny. Ci ludzie naprawdę robią piękną robotę" (Klusek 2019).

Oprócz możliwości odbudowywania relacji i pielęgnowania więzi rodzinnych, uczestnicy mają możliwość nabywania umiejętności koncentracji, organizacji i poczucia odpowiedzialności. Warsztaty mają charakter interdyscyplinarny i są mocno zindywidualizowane. W zajęciach uczestniczy zwykle ok. 15 osób. „Warsztaty zostały zorganizowane tak, aby miały walor zabawowy, ale też powodowały wzmocnienie poczucia własnej wartości uczestników, rozwijały ekspresję własnego ciała, pozwalały na upust emocji poprzez kierowanie nimi i ich rozładowanie, odreagowanie agresji, a także uczyły pozytywnej komunikacji z drugim człowiekiem, budowały atmosferę zaufania i bezpieczeństwa” (Dąbrowska, Kusztal, Turczyk 2019: 352).

Spotkania podzielone są na dwie części: pierwszą o charakterze plastycznym oraz drugą - psychoruchową, integracyjną. W czasie trwania zajęć jest przewidziana również półgodzinna przerwa obiadowa, podczas której personel ma możliwość obserwacji relacji rodzinnych uczestników przedsięwzięcia. Artur Dziwirek, fotograf dokumentujący projekt, zaznacza: „Widać było u dzieci to, że są $\mathrm{w}$ rozłące $\mathrm{z}$ rodzicami, ale te miejsca dawały dużo ciepła. Te rodziny się sklejały. Rodzice z dziećmi fajnie współpracowali, a my, pełniący rolę takich "podglądaczy» musieliśmy się tak zachować, żeby nie psuć tych relacji” (Klusek 2019). 


\section{Grupa docelowa programu}

Proces prowadzonej corocznie wśród skazanych rekrutacji do projektu jest dogłębnie przemyślany, długotrwały oraz rzetelny. Dzieje się tak, ponieważ cały cykl spotkań trwa jeden rok. W tym czasie uczestnik projektu może zostać warunkowo zwolniony czy zmienić miejsce odbywania dalszej części kary itp.

Finalnie grupa zrekrutowanych do projektu skazanych liczy kilkanaście osób. Oczywiście w warsztatach uczestniczą również ich dzieci, a także opiekunowie, kadra penitencjarna i personel teatru. Władze kwalifikujące uczestników zajęć zwracają dużą uwagę na środowisko pochodzenia osadzonych, ich poczucie wartości oraz traumatyczne doświadczenia, jakie stały się ich udziałem na przestrzeni lat. Daje to swego rodzaju możliwość odbudowania prawidłowego obrazu własnej osoby oraz odzyskania wiary we własne możliwości zaradcze. Skazani to zarówno kobiety, jak i mężczyźni, którzy poprzez czynny udział w warsztatach mają możliwość odnowienia często nikłego kontaktu z własnymi dziećmi. Jeden z nich w trakcie rozmowy stwierdził wprost: „Odliczam dni, z teatru do teatru, bo jedyny kontakt z moim synem, to jest przez ten teatrzyk" (Teatr, Mama, Tata i Ja 2019).

Grupa docelowa programu obejmuje więc odbiorców pośrednich i bezpośrednich - skazanych (kobiety i mężczyzn), dzieci, pracowników penitencjarnych oraz grupę globalną, czyli np. przedsiębiorstwa, instytucje, władze lokalne, samorządowe, krajowe, przedstawicieli środowisk naukowych, terapeutów, animatorów itp.

\section{Ewaluacja}

Ewaluacja każdego z programów penitencjarnych pozwala na zaobserwowanie, na ile został zrealizowany program oraz czy zamierzone cele zostały osiagnięte. W odniesieniu do analizowanego programu resocjalizacyjnego „ocena ta prowadzona jest od początku programu, tj. od 2015 r., na podstawie autorskich narzędzi badawczych opracowanych w ramach działalności zespołu interdyscyplinarnego powołanego przez realizatorów projektu" (Dąbrowska, Kusztal, Turczyk 2019: 354). 
Program „Teatr, Mama, Tata i Ja” podlega ewaluacji formatywnej. Oznacza to, że kontrolowany jest w toku trwania projektu na bieżąco, a więc w przypadku, kiedy jakiś element nie funkcjonuje prawidłowo, można go szybko skorygować. Ponadto ewaluacja ma określić stopień realizacji założonych celów projektu, ewentualnych barier w jego realizacji, trafności, efektywności, skuteczności, użyteczności wybranych metod terapeutycznych oraz trwałości osiągniętych skutków. „Fragmentaryczne badania ewaluacyjne prowadzone są na podstawie ankiet ewaluacyjnych dla uczestników programu, arkuszy obserwacyjnych wypełnianych przez animatorów i osoby prowadzące warsztaty kompetencji rodzicielskich i warsztaty integracyjne oraz z wykorzystaniem kwestionariuszy ramowych wywiadów swobodnych i map skojarzeń przeznaczonych dla dzieci” (Dąbrowska, Kusztal, Turczyk 2019: 355).

\section{Analiza wypowiedzi respondenta}

\section{Kryminalna przeszłość}

Jako wstęp do dalszych rozważań oraz dopełnienie wiedzy na temat wyżej przedstawionego programu może posłużyć historia pobytu w placówce penitencjarnej respondenta. $\mathrm{W}$ trakcie wywiadu narracyjnego bez wahania zaznaczył, że sam pobyt $\mathrm{w}$ takim miejscu daje człowiekowi czas do głębokiego namysłu i poszukiwania sensu życia. Odbytą w izolacji karę wspominał jako „piekło”, o którym chciałby zapomnieć, choć jest świadomy, że nie jest to możliwe. Czas ten określił jako zmarnowany, ponieważ to właśnie wtedy powinien się koncentrować na wychowaniu własnych dzieci. Swoją historię przedstawił z dużym smutkiem.

Zaznaczył, że przyczyną jego pobytu w placówce były błędy, które popełnił w przeszłości. Wskazał na przekręty i oszustwa podatkowe, które zabrały mu trzy lata szczęśliwego życia. Wyjaśnił, że nie spodziewał się po sobie, iż będąc dojrzałym mężczyzną, będzie tak „kombinował”, a jako przyczynę swojego postępowania wskazał chęć szybkiego rozwoju własnej działalności oraz dobrego zarobku.

Swój pobyt w areszcie postrzega jednak w kategoriach pozytywnej lekcji, jaką otrzymał od życia. Uważa, że gdyby taka sytuacja nie 
miała miejsca, pewnie do dzisiaj nadal łamałby prawo kierując się chęcią szybkiego zysku.

\section{Kontakty z rodzinq}

Pobyt w Areszcie Śledczym w Kielcach był dla badanego dużym udogodnieniem, ponieważ pozwalał mu pozostawać w stałym kontakcie z rodziną. Mimo wszystko rzeczywistość penitencjarna powodowała pustkę i deficyty w relacjach z bliskimi.

Nieduża odległość od miejsca zamieszkania rodziny odgrywała tutaj znaczącą rolę. Żona badanego nie posiadała w tamtym okresie prawa jazdy, stąd też zdawało się mu niemożliwe, by mając pod opieką dwoje dzieci dojeżdżała do niego na widzenia do innego miasta.

\section{Wspótosadzeni a relacje wewnq̨itrwięzienne}

Współosadzeni, którzy odbywali kary pozbawienia wolności w tym samym czasie co badany, byli różni pod względem charakterów; mieli też różne wyroki, jeśli chodzi o przyczyny skazania i czas trwania kary. On sam był osobą skazaną po raz pierwszy, natomiast większość skazanych przebywających $\mathrm{w}$ areszcie to recydywiści, osoby z góry odrzucające jakąkolwiek pomoc ze strony personelu, nieustannie się buntujący. W wywiadzie sam zaznaczał, że takie zachowania nie mają większego sensu, dlatego że przyczyną nakładania przez sąd kolejnych kar powodujących ewentualne przedłużenie wyroku. Ponadto wpływają na relacje wewnątrzwięzienne. Siebie samego określił jako jednego z "grzeczniejszych”, którzy przychodzą do placówki w celu poniesienia konsekwencji własnego postępowania i szybkiego powrotu do społeczeństwa. Mówił, że pobyt $\mathrm{w}$ areszcie odbierał osobiście jako karę za swoje winy. Nie chciał przed niczym uciekać. Zaznaczył, że teraz jest kimś zupełnie innym i odrzuca „pozorny” sposób życia. Czas pobytu w areszcie upłynął mu bez większych komplikacji i konfliktów z innymi skazanymi i służbą sprawującą nad nim ówcześnie pieczę. Chętnie angażował się w aktywności i rozmowy mające na celu korektę jego zachowania i osobowości. 


\section{Proces resocjalizacji z perspektywy skazanego}

Sposób, w jaki respondent określał proces resocjalizacji, odnosił się do samego czasu izolacji i kontaktów z personelem aresztu, natomiast największej motywacji do zmiany badany upatrywał w samym sobie. Nie negował zasadności procesu resocjalizacyjnego, natomiast osobiście uważał, że większość zmian odbywa się w człowieku dzięki jego wewnętrznym motywacjom. Zauważył ponadto, że w placówkach zamkniętych jest możliwość uzyskania pomocy od kapelanów oraz wychowawców, natomiast musi zostać to dopełnione osobistym wysiłkiem zainteresowanego.

Dla skazanego istotna okazała się również jeszcze jedna kategoria, w jakiej postrzegał dokonaną w swoim życiu zmianę. W jego przypadku proces resocjalizacji doprowadził do zmiany polegającej przede wszystkim na odstąpieniu od zachowań niezgodnych z prawem. Ponadto wypracował w sobie pewien zbiór wartości, których wcześniej nie zauważał lub które ignorował. Zyskał umiejętność kontroli własnego zachowania, panowania nad emocjami. Było to dla niego niezwykle ważne, gdyż przed odbywaniem wyroku cechował się niestabilnością emocjonalną.

\section{Resocjalizacja twórcza i programy z jej zakresu}

Respondent stwierdził, że obecność resocjalizacji twórczej jest w polskim więziennictwie widoczna i że sam jej doświadczył uczestnicząc $\mathrm{w}$ programie przeznaczonym dla skazanych i ich rodzin. Zauważył, że jest to znakomita alternatywa dla „suchej” izolacji oraz uczucia bezczynności i pustki. Mimo wszystko zaznaczył, że nie jest ona powszechną formą pracy ze skazanymi. Określił ją jako oddziaływanie na drugą osobę przez sztukę i twórczość. Jest to w miarę prosta i krótka definicja, ale jak stwierdził - tak ją właśnie czuje.

Badany został zakwalifikowany się do programu penitencjarnego „Teatr, Mama, Tata i Ja”. Uważał, że stało się tak dlatego, iż w okresie pobytu w placówce jego samoocena znacznie spadła i nie był w stanie w pełni zaakceptować nowej rzeczywistości. $Z$ żalem stwierdził, że najbardziej szkoda mu dzieci, które świadome zaistniałej sytuacji, zarówno w szkole, jak i społeczeństwie były wytykane palcami i nieustannie obgadywane. Był w stanie zrozumieć ponoszenie 
konsekwencji własnego zachowania w postaci kary skutkującej psychicznym obciążeniem, jakiego doznawał $\mathrm{w}$ areszcie, natomiast największy ból sprawiało mu zachowanie społeczeństwa, które stygmatyzowało jego dzieci. Był to przecież czas, w którym w jego synach kształtowała się osobowość. To oni odczuwali w największym stopniu konsekwencje jego niezgodnych z prawem działań.

Badany stwierdzil, że resocjalizacja twórcza ma ogromne znaczenie, bo przecież każda interwencja i działanie w jakimś stopniu wpływają na wnętrze człowieka. W jego przypadku uczestnictwo w programie ukazało mu jak ważna jest rodzina - oczywiście wiedział już o tym wcześniej, natomiast projekt uzmysłowił mu, że pielęgnacja wnętrza człowieka poprzez sztukę i równoczesny kontakt z rodziną mogą poprawiać samopoczucie i stymulować zmiany.

Respondent nie był w stanie wypowiedzieć się na temat dostępności programów z zakresu resocjalizacji twórczej w innych miejscach, gdyz - jak stwierdził - uczestniczył i słyszał tylko o jednym, ale $z$ tego, co mu się wydaje, taka forma pracy ze skazanym nie jest jeszcze dostatecznie powszechna.

\section{Uwarunkowania osobowościowe kadry penitencjarnej}

Kluczowym elementem procesu resocjalizacyjnego zdają się być również kompetencje i kwalifikacje, a także walory osobowościowe kadry i terapeutów realizujących programy. Respondent zwrócił uwagę na te aspekty. $Z$ uśmiechem na ustach oświadczył, że kadra penitencjarna składała się z osób, których po prostu nie da się lubić, natomiast realizatorzy programów starają się robić wszystko, aby współpraca układała się przyjemnie. Nie są to tylko wychowawcy, ale też szereg innych osób. Badany stwierdził, że z jego perspektywy u kadry więziennej najważniejszy jest szczery uśmiech i przyjazne usposobienie - to właśnie gwarantuje dobrą atmosferę i współpracę. Nie zanegował też, że są to w większości osoby wykwalifikowane, które wiedzą co robią. Według niego posiadają one też szereg cech charakteru, które wspomagają proces naprawczy skazanych. 


\section{Refleksje podsumowujq̨ce}

Resocjalizacja twórcza stanowi sposób oddziaływania na wychowanka za pomocą innych niż tradycyjne form, metod i środków naprawczych. Koncentruje się ona wokół sprecyzowanych celów, zmierzających do wykształcenia człowieka świadomego, uaktywniającego własne myślenie twórcze oraz twórczą osobowość. Ponadto zakłada, że sam proces powinien przygotować skazanego do życia $\mathrm{w}$ społeczeństwie oraz do zmiany obrazu własnej osoby w relacjach interpersonalnych.

Resocjalizacja twórcza, jako sposób oddziaływania naprawczego na wychowanka, powinna zajmować szczególne miejsce we współczesnej penitencjarystyce. Jednak jej założenia oraz metody nie są przedmiotem zainteresowania licznej grupy badaczy. Większą uwage temu zagadnieniu przypisują pedagodzy resocjalizacyjni, którzy nie pracują na co dzień w placówkach penitencjarnych oraz ci, którzy opisują rzeczywistość placówek dla nieletnich, jak np. Marek Konopczyński. Treści programów penitencjarnych z zakresu twórczej resocjalizacji różnią się w znaczący sposób od tradycyjnego sposobu pracy ze skazanymi. Bywa również tak, że programy resocjalizacyjne, mimo że nie zawierają podanej expressis verbis informacji o tym, że uwzględniają w swych treściach elementy metodyki resocjalizacji twórczej, mniej lub bardziej świadomie wprowadzają je do pracy ze skazanymi. Można zaobserwować to na przykładzie wyżej analizowanego programu. Należy zaznaczyć, że program „Teatr, Mama, Tata i Ja" tak naprawdę nastawiony jest na kontakty z dziećmi, a nie na sztukę samą w sobie. Można jednak zaobserwować, że dzięki wprowadzeniu jej elementów do pracy ze skazanymi i ich rodzinami sam proces naprawczy został urozmaicony i zyskał walory terapeutyczne. Twórcza resocjalizacja zdaje się być koncepcją, która może stanowić ramy dla resocjalizacji penitencjarnej. Jest to więc zagadnienie, które powinno zainteresować badaczy. Może także być inspiracją do prowadzenia badań w tym kierunku. Obecnie istnieje wiele odbywających się cyklicznie programów dla osadzonych, natomiast - jak się wydaje - wciąż jest ich zbyt mało. Jak wyznaje bohater przeprowadzonego wywiadu, taki rodzaj aktywności ma wiele walorów; dodaje jednocześnie, że dostępność tego rodzaju programów jest mocno 
ograniczona. Ponadto procesy rekrutacji do poszczególnych projektów wymagają spełnienia szeregu wymagań.

Twórczość w resocjalizacji ma bardzo duży wpływ na rozwój osobowości skazanych. To dzięki niej wychowankowie mają możliwość przewartościowania własnego życia i skonstruowania na nowo własnego świata wartości. Dzieje się tak poprzez przechodzenie od osobowości dewiacyjnej do niedewiacyjnej, co prognozuje pełne odstąpienie od zachowań przestępczych. Ważną zmianą, którą respondent zaobserwował u siebie, był wzrost samooceny i poczucia skuteczności w działaniu dzięki uczestnictwu w zajęciach oraz świadczonej mu pomocy.

Resocjalizacja twórcza ukazuje, że istnieje wiele alternatyw, chociażby dla sposobu spędzania czasu wolnego i rozwoju własnej osobowości. Dzięki uczestnictwie w procesie specjalistów z różnych dziedzin, zapewnione zostaje wsparcie psychiczne i motywacja do podążania ku lepszej przyszłości, co może stanowić mechanizm napędzający zmiany $\mathrm{w}$ pełnionych dotychczas rolach społecznych skazanych.

Poprzez oddziaływanie na skazanych przez sztukę, nieustanne umożliwianie im kontaktu $z$ kulturą, kadra specjalistyczna realizuje cele zmierzające do wykształcenia w wychowankach wrażliwości na piękno oraz pobudzenia w nich twórczego myślenia oraz rozwoju ich osobowości. Dzięki zaangażowaniu zainteresowanych w różne przedsięwzięcia resocjalizacja twórcza pozwala na zbudowanie satysfakcjonującego obrazu siebie, a także jego lepszego odbioru w społeczeństwie.

Dostępność tego rodzaju programów resocjalizacyjnych dla zainteresowanych skazanych jest mocno ograniczona z powodu warunków, które muszą oni spełnić, chcąc zakwalifikować się do projektu. Wiele $\mathrm{z}$ nich jest ukierunkowanych na konkretną grupę odbiorców w związku z zamierzonymi wcześniej celami i potencjalnymi efektami. Niektóre z nich w założeniach mają pracę ze skazanymi odbywającymi długoletnie lub dożywotnie wyroki, w celu „rekompensaty” czasu spędzonego w izolacji. Inne nastawione są na odbudowywanie więzi rodzinnych, a jeszcze inne na zupełnie inne cele. Nie każdy program jest odpowiedni dla każdego skazanego.

Główną korzyścią wynikającą z uczestnictwa w programach z zakresu resocjalizacji twórczej jest przede wszystkim szansa 
rekonstrukcji własnej osobowości skazanego. Dzięki aktywności własnej osadzeni mogą rozwijać ukryte talenty i potencjały, rozwijać twórcze myślenie, angażować się w przedsięwzięcia na rzecz innych. Dzięki programom uczą się jak zwiększać poczucie własnej wartości i sprawstwa w działaniu, a także jak kontrolować własne emocje. Oprócz tego nabywają licznych umiejętności z zakresu współpracy z innymi, na co między innymi zwrócił uwagę badany mężczyzna.

Kadra więzienna, realizatorzy programów i liczni specjaliści podejmujący współpracę ze skazanymi powinni być osobami o dobrym usposobieniu, uśmiechniętymi oraz mocno zaangażowanymi we własną pracę. Właśnie na te cechy wskazał badany przeze mnie respondent. Ponadto ważne jest, aby stale podnosili swoje kwalifikacje i wzbogacali wiedzę z zakresu pracy z osobami przebywającymi w izolacji. W danym środowisku istotna jest również odporność psychiczna na sytuacje trudne, która zapobiega szybkiemu, przedwczesnemu wypaleniu zawodowemu.

W literaturze przedmiotu można znaleźć wiele doniesień na temat specyfiki pracy z wykorzystaniem resocjalizacji twórczej, która może być pojmowana $\mathrm{w}$ wieloraki sposób, w zależności od tego, jakie metody, środki i formy pracy ze skazanymi ona przyjmuje. Jak powszechnie wiadomo, mogą być one bardzo zróżnicowane, co gwarantuje wszechstronność działalności resocjalizacji w tym ujęciu.

Powstaje coraz więcej badań i doniesień naukowych akcentujących pozytywny wpływ resocjalizacji twórczej na proces naprawczy osób pozbawionych wolności, a także publikacji przedstawiających szczegółowe cele i efekty licznych programów z tego zakresu. Wśród nich można wymienić np. rozdział w książce Renaty Szczepanik Stawanie się recydywistą (2015), poświęcony kasowaniu tożsamości dewiacyjnej z perspektywy „nowej” pedagogiki resocjalizacyjnej, czy też publikację pod redakcją Moniki Marczak Resocjalizacyjne programy penitencjarne realizowane przez Stużbę Więziennq w Polsce (2009), jak i liczne materiały dostępne online, a dotyczące konkretnych realizacji np. programu Okno na świat - arteterapia malarstwem (zob. np. Igiel, Hamera 2021).

Niemniej jednak to, w jaki sposób będzie przebiegał proces resocjalizacji jednostki, uwarunkowane jest jej wewnętrzną motywacją do zmiany i chęcią uczestnictwa w programach i aktywnościach oferowanych przez specjalistów współpracujących z osadzonymi. Ważne 
jest, aby skazani byli świadomi celowości działań i założeń z zakresu twórczej resocjalizacji i chętnie w nich uczestniczyli, pozwalając równocześnie kadrze na swobodne działania wspierające ich rozwój. W odniesieniu do respondenta, którego wypowiedzi były przywoływane w tym artykule, należy zwrócić uwagę na to, że w jego wypadku o sukcesie programu zdecydował także stosunkowo niski stopień niedostosowania społecznego. Mimo popełnionego przestępstwa, nie był on osobą wrogo nastawioną do procesu resocjalizacji, współwięźniów i kadry. Szanował normy i zasady życia w placówce penitencjarnej, nie wchodził w konflikty $\mathrm{z}$ innymi. To dodatkowy i ważny czynnik sprzyjający skuteczności tego rodzaju programów resocjalizacyjnych, który należy mieć na uwadze przy doborze uczestników tego typu programów.

\section{Bibliografia}

Ambrozik W. (2016). Pedagogika resocjalizacyjna. W stronę uspotecznienia systemu oddziatywań, Kraków: Oficyna Wydawnicza „Impuls”.

Dąbrowska A., Kusztal J., Turczyk M. (2019). Wsparcie procesu readaptacji spotecznej skazanych na przyktadzie programu "Teatr, Mama, Tata i Ja”, „Archiwum Kryminologii”, t. 41, nr 2, s. 335-363.

Igiel E., Hamera P. (2021). Okno na Świat, https:/www.sw.gov.pl/aktualnosc/zaklad-karny-w-krzywancu-okno-na-swiat [dostęp: 17.03.2021].

Klusek D. (2019). Projekt „Teatr, Mama, Tata i Ja”, czyli zajęcia teatralne sposobem na resocjalizacje, „Radio Kielce”, 6.12.2019, https://m.radio.kielce. pl/pl/post-95969 [dostęp: 17.03.2021].

Konopczyński M. (2007). Twórcza resocjalizacja. Ksztattowanie nowych tożsamości, [w:] B. Urban, J.M. Stanik (red.), Resocjalizacja, cz. 1, Warszawa: Wydawnictwo Naukowe PWN.

Konopczyński M. (2012). Twórcza resocjalizacja - zarys koncepcji metodycznej, „Probacja”, nr 2, s. 35-68.

Konopczyński M. (2014). Twórcza resocjalizacja. Zarys koncepcji rozwijania potencjatów, „Resocjalizacja Polska”, t. 7, s. 13-28.

Konopczyński M. (2018). Pedagogika resocjalizacyjna - w kierunku twórczej resocjalizacji, „Nauki o Wychowaniu. Studia Interdyscyplinarne”, t. 6, nr 1, s. 64-75.

Łobocki M. (2010). Wprowadzenie do metodologii badań pedagogicznych, Kraków: Oficyna Wydawnicza „Impuls”.

Machel H. (2006). Sens i bezsens resocjalizacji penitencjarnej-casus polski. Studium penitencjarno-pedagogiczne, Kraków: Oficyna Wydawnicza „Impuls”. 
Marczak M. (red.) (2009). Resocjalizacyjne programy penitencjarne realizowane przez Stużbę Więzienna w Polsce, Kraków: Oficyna Wydawnicza „Impuls”.

Szczepanik R. (2015). Stawanie sie recydywista. Kariery instytucjonalne osób powracajacych do przestępczości, Łódź: Wydawnictwo Uniwersytetu Łódzkiego.

Teatr, Mama, Tata i Ja, „YouTube”, 6.12.2019, https://www.youtube.com/ watch?v=SzvfMddkBNg\&t=28s [dostęp: 17.03.2021].

Wysocka E., Ostafińska-Molik B. (2019). Osobowośś i myślenie twoórcze osób niedostosowanych spotecznie w kontekście resocjalizacji twórczej, „Resocjalizacja Polska”, t. 18, s. 149-170.

\section{ADRES DO KORESPONDENCJI}

Magdalena Posłowska

Akademia Ignatianum w Krakowie

e-mail: 14961@student.ignatianum.edu.pl 